\title{
Cristina Florescu (ed.), Terminologia meteorologică românească a fenomenelor atmosferice (știinţific versus popular), Editura Universității „Alexandru Ioan Cuza”, Colecția Dicționarele Editurii Universității, Seria Lexikon, Iași, 2015,711 p. (cu CD-Rom)
}

\author{
Cosmin Căprioară* \\ Faculty of Letters, "Ovidius" University of Constanța, Aleea Universității 1, 900472 Constanța, Romania
}

A new fundamental work has recently been printed by the "Alexandru Ioan Cuza" University Press, in the "Lexikon" series of the "Dictionaries" collection: Terminologia meteorologică românească a fenomenelor atmosferice (științific versus popular) [Romanian meteorological terminology of atmospherical phenomena (scientific versus popular)].

The book is the fruit of the efforts of a research team from the "A. Philippide" Institute of Romanian Philology of the Iași branch of the Romanian Academy, involved in a project funded by the National Council for Scientific Research, and consists of two independent, yet complementary sections, namely Dicționarul fenomenelor atmosferice [The Dictionary of Atmospheric Phenomena] (DFA) (p. 325-678), a pioneering lexicographical work in this country, and a set of studies on the lexical corpus compiled for the dictionary and on various aspects of the terminology of atmospheric phenomena (p. 7-324). It begins with an introduction written by Cristina Florescu, editor and leader of the team responsible for the implementation of the project, a well-known linguist, both nationally and internationally, lexicographer, Romanist, and contributor to Dictionnaire Étymologique Roman (DÉRom).

The volume also features an extensive general bibliography (p. 679-701) that also includes the DA/DLR acronyms and abbreviations, data about the dissemination of the project (p. 703-707), and an Authors' Foreword (p. 7), paralleled by brief presentations of each contributor, placed at the end of the book (p. 709-711). The material of the volume is partially recorded on a CD-ROM, which only increases its accessibility and usefulness.
As indicated from the very beginning, "the book is an in extenso study of a Romanian terminology, analysed diastatically, diatopically and diachronically", and includes "two sociolinguistic registers of the language, i.e., literary (the scientific language of meteorology) and popular (dialects and common language)" (p. 7). It constitutes, at the same time, an example of inter- and trans-disciplinary research, being the fruit of the cooperation between linguists and meteorologists, and consequently, the number of domains involved becomes extremely large, if we are to consider meteorology as a branch of geophysics.

From the start, the open character of meteorological terminology is emphasized, which represents not only a pertinent observation, but also suggests that this terminology may be enriched, if only on the side of popular language. On the other hand, meteorological terminology was selected and structured in a rather restrictive manner: the terms of the DFA "were chosen on the basis of the circulation of their denotativity" (p. 7), which means that only those lexical elements with a denotative character have been retained. As far as possible, stylistic and affective factors have been disregarded.

The Introduction (p. 9-29) ${ }^{1}$, signed by the editor of the volume, and conceived as a study in itself, with its own bibliography, is both a useful and an interesting presentation of the progress on the compilation of the dictionary, of its structure, of the principles that motivated the selection, organization, and definition of the terms. The analysis of the corpus is generally semasiological, without excluding the onomasiological perspective. Regarding the object of study,

\footnotetext{
*Email address: ct.caprioara@yahoo.fr.

${ }^{1}$ In what follows, we shall pay careful attention to the Introduction, since it actually lays down the methods and the principles of selecting and organizing the material of Dicționarul fenomenelor atmosferice [The Dictionary of Atmospheric Phenomena]. Our commentaries are also aimed at the lexicographic work.
} 
the author specifies the metalinguistic terms used, and formulates the objectives and the paths chosen to reach them. Thus, "atmospheric phenomena (the states, the processes, etc.)" (author's emphasis) were taken into account, and not "the language of climatology, hydrology, or agrometeorology, the denominations of the cosmological or telluric elements, the terms that name the extremely complex instruments of meteorology (described in detail in any meteorological dictionary), the principles / processes / theories of physics and mathematics, the words, based on the theory of approximations that designate predictability, those belonging to statistics, lexemes that represent pollution factors, those specific of marine prognoses, ecological analyses, etc." (p. 9). After such an enumeration, we cannot but agree with the author, when, in a plastic manner, she compares meteorology with an ocean, in the study of which physics, geography, mathematics, informatics, automatics and system engineering, biology, botanic, geology, medicine and others intertwine holistically. At the same time, we cannot help noticing what a daunting task those who compiled the DFA took upon themselves. The more so as the meteorological language is different from other languages of specialty, due to its open character, based on its functionally dominant of predictability.

Placing the research in two registers, i.e. literaryscientific and popular, gives the author the opportunity to go down into the history of the two types of terminology. She points out the role played by the Bucharest school, led by Angela Bidu-Vrănceanu in standardizing scientific terminology, and the significant contributions of Ov. Densusianu, S. Pop, Șt. Pașca, Gr. Antipa, T. Pamfile, and S. Fl. Marian made for the development of popular terminology. The author rightly comments that "most of the linguistic analyses of various popular terminologies have always considered, at least theoretically, their relation to the scientific terminology", yet a comparative study of the scientific terminology and the equivalent popular terminologies has attracted less interest (p. 12). Following Angela Bidu-Vrănceanu (Terminologie și terminologii, Editura Universităţii din București, 2010, p. 13-16), a crucial distinction is made, between internal terminologies (i.e., terminologies "strictly interpreted in relation to the problems of specialized communication") and external terminologies, which include the specialized lexis from various domains.
Extremely important is the observation that, unlike most terminologies, the meteorological one does not position itself at the periphery in its relation to common language.

We have found extremely useful the analysis of the rapports between scientific terminology $(\mathrm{St})$ and the popular one $(\mathrm{Pt})$, in general (p. 13-14), since, in relation to both, meteorological terminology preserves a certain specificity: it is more archaic and contains more terms with obvious distinctive features, which belong to the principal lexical fund. Several specialized terminologies are briefly analysed, such as those related to ancient crafts (rafting, moccasins making, egg decoration, etc.), which, practically, have no scientific equivalent, those of old crafts that have adapted themselves to new technical and civilizational realities (building, animal raising, textile and food industry, etc.), in which numerous common terms appear, that of medicine, where, up to a certain level, a some parallelism terminological between $\mathrm{Pt}$ and St has developed, and the terminologies of the new domains of knowledge (informatics, mechanics, plasma physics, aeronautics, etc.), which although exclusively placed in the sphere of scientific language, are however familiar to the large public by means of the mass-media and education.

The Introduction also provides the necessary information on the stages of the research, and the structure of the volume (p. 15-17). Based on the abovementioned theoretical considerations, the research team conceived the DFA as "a lexical database and as illustrative material for the Linguistic study [Studiul lingvistic], which makes up the former part of the volume, in fact a sum of studies grouped per the lexical fields they belong to" (p. 15). We must state that not all the terms in the DFA have come under the scrutiny of those who authored the studies (e.g. those that designate "fine/bad weather"). Those elements of the weather forecast bulletins, which are thought to be specific of journalism, and which "position themselves between (...) scientific terminology and common address" were left aside too (p. 16). In addition to these linguistic studies, undertaken during the second stage of the project, the introduction pays tribute some renowned Romanian linguists (Maria Iliescu, Rodica Zafiu, Mariana Neț, Nistor Bardu), who participated in the project workshops, decisively contributing to its success with studies on various meteorological topics, and to Liviu Apostol, the au- 
thor of a very accurate and detailed presentation of the evolution of Romanian meteorology.

The radiography of Romanian meteorological terminology allowed the scientists to identify and observe several categories of data: common lexemes (central, complex) which circulate both in $\mathrm{St}$, and in $\operatorname{Pt}$ (brumă [frost], ceață [fog], cer [sky], fulger [lighning], fulgera [to strike], ninge [to snow], nor [cloud], ploaie [rain], ploua [to rain], vijelie [storm], etc.), terms characteristic of $\mathrm{Pt}$, yet which are sometimes used in the common language as well, especially due to weather bulletins (bură [drizzle], bura [to drizzle], fulguială [snowflaking], nea [snow], omăt [snow]), lexemes characteristic of idioms (aligni [to blow], bujală [heat], chidă [hoar frost], cocăt [scorching heat], oblăcei [little clouds], smicli [to flash], ticloi [icicle], vocot [blizzard], etc.), therefore "with more restrained Pt diatopic circulation" (p. 15), and terms exclusively belonging to St (intemperie [bad weather], nebulozitate [nebulosity], precipitație [precipitations]), which become general at the level of literary language, lexemes specific of $\mathrm{St}$ (calvus, calotă [calotte], in the syntagm calotă de nori [lit. calotte of clouds], givrare [icing], nimbus, stratopauză [stratopause]).

Important, too, are the specifications connected to those elements that - with some exceptions-have not been included neither in the DFA, nor in the related studies. Most of them are dialectal elements, and the reasons for their exclusions are connected to: "a) the relative low number of their attestations, b) their expressivity, which does not respond to the demands of the research, c) their non-inclusion in a systematic lexical family, d) or, on the contrary, their elementary framing in a derivational system which makes their attestation susceptible of individual innovation, etc." (p. 17). The necessity of these criteria is beyond doubt, and any commentary on them seems superfluous, however, some constructive observations may be made on the way they are applied to concrete cases.

The selection of terms was indeed a difficult process, which passed through several stages. In the first one, the team attempted to identify the scientific terms on the basis of meteorological texts, yet the lack of any specialized study, "systematized on the basis of philological-lexicographical norms", "the time spent to discriminate between various polysemies, homonymies, and especially synonymies" (p. 18) proved to be too long, and only made the situation worse. At the same time, substantial decisional effort was needed, to establish some borders between the different domains of meteorology. In the second stage, the team established the complex St $+\mathrm{Pt}$ terms, which underwent significant alterations until the last moment. The third stage involved the selection of the regional terms, which sometimes are difficult to circumscribe denotatively, due to their expressive and affective charge (see, for instance, the relationships facilitated by language, between the atmospheric phenomena and one's states of mind, Elena Slave's Metafora în limba română, Editura Științifică, București, 1991). Diminutives and augmentatives were carefully and rigorously selected.

Of great interest is the information about the criteria used to identify atmospheric phenomena (which presupposed real intradisciplinary work), also the bibliography from which the terms were excerpted (general dictionaries, dictionaries of synonyms and neologisms, and encyclopedic and meteorological dictionaries, those online included, geographical dictionaries, dictionaries of nautical terms, maritime dictionarists), old texts, such as Lexiconul de la Buda [The Lexicon of Buda] $\left(\mathrm{LB}^{\mathrm{e}}\right)$, the electronic variant included, dialectal texts, works in geography, physics and meteorology, literary texts, as well as a comprehensive review of the research on atmospheric phenomena (p. 19-24).

The corpus was compiled on the base of the 37 volumes of Dicționarul limbii române al Academiei DA/DLR [The Dictionary of Romanian, issued by the Romanian Academy]. Almost 200000 different entries in the dictionary were analysed, because some words, such as a la, may have meteorological meanings too. Since the share of the regional element is large, dialectal glossaries, collections of dialectal texts, all the relevant maps from the Romanian linguistic atlases, the dialectal material found in manuscripts included, as well as Dicționarul graiurilor dacoromâne sudice [The Dictionary of Southern Daco-Romanian Dialects] (DGDS) were also widely consulted.

Defining lexicographically the terms that appear both in $\mathrm{St}$ and $\mathrm{Pt}$, so that this should cover both diastratic variants (see the cases of arșiţă [scorching heat], austru [dry wind], bură [drizzle], căldură [warmth], ploaie [rain], timp [weather], vreme [weather], etc.) proved to be extremely difficult. Whenever popular 
and the scientific usage are dissociated polysemantically in the DFA, this is strongly supported by marking the specific differences between them, through definitions, examples, and sources (cf. DFA, s.v. GHEAȚĂ [ice], LUMINĂ [light], TUNET [thunder], VÂNT [wind], etc.).

Practically, throughout the research process, the linguists involved continuously perfected their interdisciplinary skills [see the example of the deep understanding of the conceptual field of radiation (which involves light and heat) and of depositions (brumă, chiciură, zăpadă, gheață, etc.)], out of which a solid research resulted, that omits no important element!

Little linguistic research on meteorological terminology has been carried out so far: the most significant contributions are those of José Enrique Gargallo Gil (coord.), Paremiología romance: los refranes meteorológicos (Barcelona, 2010), and Kurt Baldinger, Dictionnaire onomasiologique de l'ancien Occitan (Tübingen, 1975-2007, especially the first volume of the ten), for Romance languages, and those of Florica Dimitrescu, Rodica Zafiu and Pârvu Boerescu, for Romanian.

In a separate paragraph, the lexical and semantic fields of meteorological terminology, as they result from the dictionary, and which are further examined in the linguistic studies that precede it: nebulosities, winds, movements of air currents, precipitations, depositions, light and sound phenomena, and radiations. One should notice that there is inherent overlap between them: for instance, fog (seen as precipitations and nebulosities), snow, glazed frost (as depositions and precipitations), and, consequently, they are treated complexly, further information about their status being provided. The authors use the notion of "lexical-semantic field" in its broad sense, morphologically heterogenous, and includes, in addition to nouns, verbs and adjectives.

"Cultisms" or the "encyclopedic" terms, which are rare and sometimes artificially constructed linguistic elements by well-educated people under the influence of mythology of classical languages, such as acvilon [northern wind], deger [frost], levante [eastern wind], procelă [storm], zăpădoc [snowflake], etc., are then added to the three types of diastratic phenomena (St, Pt, Pt/St).

A set of conclusions (p. 25-29) ends this rich, informative introduction: "The research is a pioneering work in Romanian linguistics, as it is the only one that has as its object of study the lexical group that designates atmospheric phenomena in Romanian, and traces them at the level of both literary and the popular language (in its broad sense: the dialectal and common element). No extended comparative analysis of scientific terminology and its equivalent popular terminology" (p. 25) was conducted before this project. Specialized lexicographical techniques (simplified and adapted to the object of study) are used. Essential for its success has been the cooperation between linguists and meteorologists.

Finally, the author carries out a review of the main results of the research:

a. To identify the earliest attestations of some of terms and/or their meanings.

b. To consider and mark the classes of verbs and adjectives.

c. To retrieve, by means of dialectological and lexicographical systematization, words, senses and syntagma that designate atmospheric phenomena, at the level of popular language, (such as: aburel de vînt [light wind], bastara [summer fog], mizguială [light snowflaking], rodină [sunny rain], etc.).

d. To record archaic terms (e.g.: alizat, meteor).

e. To identify, restructure or nuance the etymologies of some popular and scientific terms (see brumăroacă [a kind of rime], brumă [rime], pîclă [mist], etc.).

Due to its close connection to the elements, Romanian methodologic terminology is extremely rich. Although it has fallen under a strong anglicizing influence of late, after having experienced the influence of French earlier, it remains strongly anchored to the terra firma of common language, which refreshes it continuously (see, for instance, the denomination chiciurometru for an instrument of measuring precipitations!). Etymologically, and as structure of words, meteorological terminology replicates, the very image of Romanian.

The first part of the book brings together two categories of studies. Firstly, the studies of the researchers involved in the project, covering the five lexical and semantic fields mentioned above, provide an indepth analysis of the terminological corpus which makes up the dictionary of atmospheric phenomena, and intersect with an interesting dialectological 
analysis. Secondly, a series of studies on the same topic, yet which are not strictly based on the DFA corpus, done by personalities of Romania meteorology and linguistics, and of Romance linguistics. A very useful Index of Words and Variants (p. 213-228) is conveniently placed between the two categories of contributions.

The first lexical-semantic field is analysed by Cristina Cărăbuș, in her study Nebulozitățile [Nebulosities] (p. 31-45). As in all introductory studies a certain algorithm at work is observed, which basically includes the following: the definition of the object of study, the description of scientific terminology used, the typology of the phenomena described (clouds in this case), the description of the popular terminology, pointing out synonymies, the terms and the syntagms preserved in the studies only, yet eliminated from the DFA, and conclusions.

Extremely useful for the whole book is her discussion on the nature of syntagm (a stable combination), for which the author appeals to prestigious works in the field.

Unlike the variety and large number of denominations in the scientific terminology, their number in the popular language is much smaller (20 terms with variants: 12 nouns +6 adjectives +2 verbs), the rapport being $88 \%$ to $12 \%$. Their etymologies are carefully explored. It is interesting that of all the terms that designate or refer to nebulosities, only nor [cloud] is inherited, 14 terms (cca 21\%) being formed in Romanian. The syntagms, extremely numerous (98 in number), belong exclusively to St. They are exhaustively and consistently treated. Their models are French and English, yet an observation must be made, namely that some of them could be "calques of calques", in the sense that, for example, the syntagm from English, taken over by Romanian authors, could have been itself a calque from the corresponding syntagm from French, and vice versa. However, it is important that the Romanian specialists could have borrowed the terms from either language or even from both!

Some adjacent clarifications and suggestions could be made regarding the etymology of some terms: corcolani (attested in eastern Oltenia) "thick clouds that appear especially in summertime", with unknown etymology in the DFA, could be connected to the verb a (se) corcoli " 1 . To take exaggerate are of someone; to pamper, coddle someone; 2 . to linger long with something, to waste one's time; to delay" (DEX 2009, s.v.), to which "to sleep, to cuddle" (DAR 2002, s.v.) could be added. Scriban explains it regarding children, especially when they are excessively cuddled, or cocooned in warm, airy clothes by their parents. Or, these clouds have this fluffy appearance too. Another observation which the author makes on two occasions (p. 39-40, 45), and on which we should have insisted on, is the etymological status of some denominations of cloud types, in current dictionaries (MDA, DLR). While Pileus, Stratus, Virga are thought to have a double etymology, from scholarly Latin and from French, Altocumulus and Albostratus are given as deriving only from French etymons (altocumulus and albostratus, respectively), and Fibratus and Genitus, having a French and English origin (fibratus and genitus), respectively. We think that the scholarly Latin form should also have been taken into consideration in these cases as well, the more so as the Latin model is transparent, and the ordinary pronunciation from French and English did not count for Romanian specialists, when they used these terms for the first time.

In connection to the meteorological terms analysed, yet which were not included in the DFA, we believe that, indeed, strict technical and scientific terms do not have their place here, because of their too great specialization and the related domain they belong to (instruments, sizes, etc.). However, at least some of the diminutives of nor (noricel, norişor, nouraş, noruleț, noruț, nourel) should have been preserved, despite their expressive and affective character, because, effectively, they are used in common Romanian as denotation for the concept of "small cloud". See also the case of răzişoară, kept in the dictionary despite its obvious expressive value! Furthermore, popular terms, even diminutives and augmentatives, which have a certain stylistic charge, when placed in a "meteorological" context, may "objectify themselves", in other words, they denote, while the affective factor, though preserved, remains in the background.

The next study, entitled Vânturile, deplasările și curentii de aer [Winds and the movements of air] (VDC) (p. 47-70), is signed by Alina-Mihaela Bursuc. It begins with a review of the general features of St and Pt regarding VDC. Observing the same work algorithm, the author describes the situation of the previous analyses of the VDC, and retains, for Romanian, those of Tr. Gherman, of 1924 (Vin- 
tul în credințele populare), M. Sala, of 1987 (Două lecturi ale "Atlasului lingvistic mediteranean"), Al. Niculescu, of 1993 (Orient și oocident in terminologia maritimă românească), P. Boerescu, of 2011 (Cuvinte româneşti cu "etimologie necunoscută" ...), and for the Romance space, the work of M. Alleyne, of 1959 (Les noms des vents en gallo-roman), and its bibliography. Describing the object of study, the researcher from Iași pertinently traces the differences/similitudes between the perspectives of the meteorologist, the dialectologist and/or the ordinary speaker, and the criterion of delimiting the VDC, within the wider framework of the terminology of atmospheric phenomena, the point of individualization and superposition of $\mathrm{Pt}$ and $\mathrm{St}$, as well as the referential superposition of the terms in the field of the VDC with other fields, such as precipitations, e.g. furtună, vijelie, viscol ("complex elements"), and comments on the synonymic richness of the $\mathrm{Pt}$, from where they were taken over by St. The selection of the terms was made from a rich and adequate bibliography, and those with unique attestations susceptible of expressivity have not been preserved in the dictionary. From the analysis of the VDC some general observations derive: the neologistic character of all the terms in the $\mathrm{St}$, borrowed or calqued from French and English (for the finesse of the etymological analyses see p. 61-62 and 64-65), the large number of syntagms with an adjectival determinant, in the same diastratic variant, hence a series of phonetic, orthographic and orthoepic problems, the impressive diversity of the winds denominations in the $\mathrm{Pt}$ and of their etymology (in addition to borrowings from neighboring languages, derivatives predominate).

Cristina Florescu signs the study that analyses Precipitațiile [Precipitations] (p. 71-105). An experienced lexicologist and lexicographer, the author, pursuing to certify the generic term precipitație, uses the opportunity to bring up some organizing principles of lexicographical organization in DA/DLR (p. 72-73) and, consequently, the definition of the definition the lexeme. With reference to the bibliography of the problem, she notes the absence, to date, of a totalizing study of this field.

In the sphere of precipitations, five lexical groups / subfields are identified, which, in turn, are analysed from the perspective of both diastratic varieties: ploaia [the rain], ceața [the fog], zăpada [the snow], grindina [the hail], lapovița [the sleet]. On this occasion, she reviews the principles for which certain terms with a weak position in the system have either been excluded or preserved (p. 82-97). Thus, the diminutives ploiță, ploicică are accepted, despite their expressive value, because of their frequent use and citation (unlike norişor, noruț, etc. from Nebulozități). In the lexical-semantic subfield of ploaie [rain], the largest, and with elements that could be classified according to a dominant feature (intensity, duration, droplet structure, effect on terrestrial elements), one may notice the different value of the syntagm ploaie torențială, in St as compared to Pt. In the case of potop [flood], "an unreal, referentially exacerbated notion" (p. 88), essential is the short duration. In the subfield of ninsoare [snow], there are no specific elements in St, ninsoare being the "prototypical center of the subgroup", and not zăpadă [snow], seen mostly as deposit. One must also note the synonymic richness of fulg [snowflake] in $\mathrm{Pt}$, and the high degree of cohesion of its synonymic series. In the subfield of grindină [hail], "the most prolific lexeme as far as regard synonymy is concerned", in the DFA, grindină [hail] itself and măzăriche [hail with very small frozen pellets] are prototypical (p. 93). As for ceață $[f \circ g]$, the researcher notes a great diversity in the taxonomy of the respective atmospheric phenomenon, which denotes "an extended prototypical semantics" in the terms of G. Kleiber (p. 94). Finally, the subfield lapoviță [sleet] contains "only (emphasis in the original) lexemes which signify states that include intermediary mixed atmospheric processes" (p. 96). We signal the possibility of adding, possibly in a future edition of the work, a regional term from Oltenia, cioflişcă "sleet; wet, partly melted falling snow", rather widely used in the south of Gorj county and in the east of Mehedinți county, known from the native patois, and tîrmoceală, with the same meaning, from southern areas of Dîmbovița county. These could be placed in the category of precipitations and depositions of the Pt. We also think that $z o i$, pl. zoiuri, a neuter noun, also known in the dialect from Oltenia, should be defined separately and not by means of zoaie, where the semantic feature "short, rather strong/violent rainfall", which it possesses in Oltenia, does not appear at all.

From the viewpoint of grammatical structure, notable is preponderance of feminine nouns and the remarkable capacity of generating meteorological 
verbs (over 50), especially in Pt. Compounds are absent, but there are many stable words combinations (cca 250), that is, "compounds, idioms, syntagms, and other (less stable) combinations of words" (p. 97).

The section on etymology provides us with further clarifications: only those words with a clear, widely accepted atmospheric meaning in Romanian (such as piatră "hail" < Lat. petra "ib.", vărsa "to rain heavily" < Lat. versare "ib.") are thought to have been inherited from Latin, while in case of those whose atmospheric meaning is still uncertain, a Latin origin is suggested (cerne - cf. Lat. cerno, -ere). Very interesting are the etymological interpretations of fluture "flake", whose entire "lexical evolution occurred in Romanian" (p. 101), and of zăpadă [snow], which, A. Philippide and Aug. Scriban linked to the Old Slavonic (zapad $\breve{u}$ ), not as post-verbal from

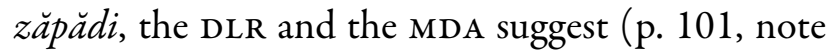
53). Notable in the DFA, in comparison to other current dictionaries of Romanian, is the dissociation of BURA $\breve{A}^{1}$, most likely a substrate element, from BURA $\breve{A}^{2}$, with Slavonic origins.

Elena Tamba focuses her attention on Depunerile [The depositions] (p. 107-127), a complex domain, difficult to explore. Among others, a first problem which the authors of the DFA had to surmount was that the terms designating depositions (brumă, chiciură, rouă) do not seem to have an acknowledged [+ meteorological] feature in $\mathrm{St}$, although depuneri [depositions] enters the definition of the generic terms meteor and hidrometeor, which belong to this terminology. The author makes an additional specification in defining depunere [deposition], namely this may also appear on objects located in the water, or in the air, not only on those located on land. As with precipitations, there are no totalizing studies. In line with the treatment of the other fields, all the atmospheric phenomena from the DFA fall within deposits, cca 130 terms, are recorded alphabetically. The principles of preserving or eliminating certain terms from the lexical domain are also explained. From our point of view, it would have been preferable not to eliminate $d u l$ and poșor, as long as ciubuc, dîlmă, fișic (all meaning "icicle") and zäpădoc (attested only in the magazine "Viața Românească" from 1964!) have been kept. Several important verbs from this field are missing: troieni, nămeți, and the reflexive înzăpezi!

Overlaps with other categories of phenomena are interesting, and so are the $\mathrm{Pt} / \mathrm{St}$ correspondences (see the cases of polei, p. 114, zăpadă, p. 115, etc.). Lexical-semantic subfields are richer in the case of țrțur [icicle] (39 synonyms), chiciură [hoarfrost] (23 terms), troian [snow-drift] (19 terms), polei [glazed frost] and sloi [floe] (8 synonyms each), and much fewer for zăpadă [snow], brumă [hoarfrost], roua $[\mathrm{dew}$ ], the last one having no synonyms. Linguistic analysis shows that, of all the 98 terms (predominantly nouns, but also verbs and adjectives), belong to the common and popular register, being autonomous words, with self-contained meaning, few polysemous words, and a few syntagms. Only 9 terms are common to those two types of language. Etymologically, few common and popular denominations are inherited, among them bură [drizzle], as a substrate element, but also brumă [hoar-frost], gheață [ice], nea [snow] and rouă [dew]. Some Slavic loans and several neologistic ones add to these. However, derivatives predominate. As far as ghețar is concerned, we do think that we must take into account not only the literary form (explainable through derivation from its French equivalent), but also the term ghețar "icicle" from Bucovina, which could be older and formed independently of the foreign model. As for the words in St, most of which are neologisms, we do not agree that ablațiune [ablation], acreție [accretion], acumulare [accumulation], depunere [sedimentation], firn [kind of glazed frost], givraj, givrare [icing], neveu [kind of glazed frost] belong "exclusively to the familiar and popular registers” (p. 124), except, perhaps, for few of them!

Cristina Cărăbuș studies Fenomenele luminoase, sonore, electrice și electro-luminoase [Luminous, Sound, Electrical and Electrical-luminous Phenomena] (p. 129-143). Luminous phenomena (balou [the halo], coroana [the crown], curcubeu [the rainbow], miraj [the mirage], etc.), are also called photometeor (optic meteor), and of them the best known is the rainbow, which represents the prototypal element both in $\mathrm{Pt}$ and in St. In connection to these, one may remark a real misbalance between the St inventory ( 44 terms, most of them nouns, numerous-syntagms and constructions, in addition to the phrase fata Morgana "mirage") and the Pt one (12 elements, among them the phrase apa mortilor [lit. 'water of the dead'] "mirage", and several combinations of words which denote the rainbow, most of them rather poetical: brîul Cosînzenii [lit. 
'Cosînzeana's belt'], brîul Domnului [lit. 'God's belt'], cununa cerului [lit. 'the crown of the sky'], etc., see p. 133). Regarding the sound phenomena (acoustics), tunet [thunder] is the prototypical term, yet, in this case, $\mathrm{Pt}$ is quite rich (10 terms), while the St is fairly poor (only 3: suier [whiz], tunet [thunder], undă acustică [acoustic wave]). Electrical phenomena, and electro-luminous phenomena (also called electrometeors and luminous or electric meteors) are represented by fulger [lightning] and trăsnet [thunder], and St (22 terms and 34 syntagms) dominates the popular terminology (with only 30 terms: nouns, adjectives, verbs).

A correction should, however, be made concerning insenina, which on p. 136 is given as circulating in Wallachia and Oltenia, in connection to clouds, with the meaning "a fulgera" [to flash], while in the dictionary (s.v.) it appears (correctly, we believe) with the above-mentioned meaning in Maramuress and northern Wallachia. Conversely, it is true that a fulgera with the meaning of "a se însenina" [to clear up] is well-known in Wallachia and Oltenia (see DFA, s.v.).

As expected, more synonyms of the prototypical terms in each category are recorded, while etymologically, borrowings from French predominate. About aurora, we think that it should not be placed among the elements inherited form Latin (p. 137), given its position and frequency in the common lexicon, the authors of DELR (M. Sala and A. Avram) giving it, probably, as a borrowing from Latin (cf. DFA, s.v.), especially because its earliest attestations are no older than the $19^{\text {th }}$ century, eventually from 1796.

Laura Manea’s task was to deal with Radiații [Radiations] (p. 145-181). The domain is less known because of its reduced mediatization and its proximity to the specialized language of physics. Consequently, most of the terms in this field are scientific: lexical borrowings, calques and, rarely, internal creations. Naturally, there are several popular terms, in fact more regional than popular, the etymologies of which are rather difficult to establish. The key term is radiație [radiation], in connection to which, the author considers it necessary to offer us a true lesson on popularized science (p. 147-152). Then, given the complexity of radiation phenomena, she enumerates and defines the principal categories of terms which belong to the this field. For $\mathrm{Pt}$, where synonymy is well-represented, one should mention the synonymic series of arșiţă ( 57 words, of which 17 are common and popular and 37 regional). For regionalisms, their area of spreading is indicated, as far as this was possible.

A more serious lexicographic problem, concerning the choice of the head word can be noticed in the case of crăpăt and crăpet. The former, according to the MDA (which follows G. Pascu), derives from crăpa, with the suffix - ăt, while the second is a variant (although, according to Pascu, the suffix is different, $-e t$ ) and, consequently, in the DFA, reference is made to crăpăt, where, however, after the definition, a quotation including crăpet is given. Naturally, the authors of the article may have had their reasons to do so, however the problem needs to be reflected upon, at least.

Taxonomically, Pt contains about 90 terms, and St about 49, yet a much larger number of syntagms: 115. One must appreciate the accuracy of the etymological analysis, as well as the case study regarding heat (p. 174-175), which points out the difficulties the authors of the linguistic laboratory confronted with, as well as the analysis of the interferences, interdisciplinary interpenetrations and terminological overlaps with other domains of knowledge.

In connection to these studies, it is worth noticing the unity of approach, in solving the problems encountered and of presentation, although the authors exercised freedom, especially in structuring their materials!

Given the complexity of researching popular meteorological terminology, the team also included a dialectologist. The corresponding subchapter, $A s$ pecte dialectale [Dialectal Aspects] (p. 183-212), is signed by Florin-Teodor Olariu, who also contributed to the Noul atlas lingvistic pe regiuni: Moldova si Bucovina [The New Linguistic Atlas on Regions: Moldova and Bucovina].

After offering valuable information on the documentation on the dialectal material, a task for which the researcher consulted the DA/DLR thesaurus, Dicționarul graiurilor dacoromâne sudice [The Dictionary of Southern Dacoromanian Dialects] (DGDS), the Romanian linguistic atlases (ALR SN, ALRM SN, ALRR/NALR, ALM), as well as collections of dialectal texts and dialectal glossaries from Oltenia, Muntenia, and Dobrudja, also included in the DGDS. At the end of this activity, about 700 
terms ere excerpted, of which the author retained cca 400 dialectal elements and for which he provides a detailed linguistic (phonetic, morphological, lexical, semantic and etymologic) analysis.

In relation to the phonetic component, F.T. Olariu brings into sharp focus the delicate problem of literalization / literarization (largely debated on recently by I. Mării, in 2004, and A. Avram, in 2014). Its exact understanding, claims the researcher, may prevent etymological distortions of some dialectal terms, as it happens with miźgura "to sift; to rain thinly", from Banat, which must have derived from *migigura, and not from *migegura. Of great interest are the solutions chosen for the extremely difficult problems of transliteration, (as in the case of the Cyrillic grapheme k, p. 188), and of selecting the base variant (e.g. țurțr).

Morphologically, the different plural variants of some names and the presence /absence of grammatical suffixes for the present indicative and subjunctive raised some problems. Subtle too are the author's observations on the idiomatic (in)competence of the subject of the dialectal enquiry (p. 200).

The last part of the study focuses on the diatopic analysis of the excerpted material, and draws attention to the linguistic vitality of some meteorological terms, which appear in the first investigations of the ALR, as well as in those for the ALRR/NALR. The author also opines that the existence of some linguistic islands based on meteorological terminology could be more easily demonstrated in the conditions of the denser dialectal network and the new regional linguistic atlas (e.g., a se guri "a se însenina”, compactly used in North-Eastern Oltenia and North-Western Wallachia). Moreover, the cooperation with a dialectologist proved to be extremely useful. This way, one of the main achievements of the DFA "is represented by the introduction in Romanian lexicography, at the level of popular lexis, of some new lexemes, variants or meanings." (p. 211), and, thus, the DFA "becomes, not only the first Romanian dictionary which comparatively analyses (scientific vs. popular) and on large scale the terminology specific of a lexical field (i.e., of atmospherically phenomena), but also the Romanian lexicographic work with the most up to date documentation at the dialectal level" (loc. cit.).
The final section of the former part includes the very useful and comprehensive survey of the history of Romanian meteorology, written by Liviu Apostol, academic and meteorologist, and the articles on meteorological-linguistic topics contributed by some well-known Romanian specialists: Maria Iliescu, Rodica Zafiu, Mariana Neț, and Nistor Bardu.

In his Considerații privind dezvoltarea meteorologiei în România [Some Considerations on the Development of Meteorology in Romania] (p. 229240), Liviu Apostol insists on the description of the institutional growth of meteorology, which provides a genial framework for the other components, and for some aspects regarding the beginnings of this science. Practically, the earliest scientific meteorological observations date, in Romanian, from the end of the 18th century. Its rapid synchronization of the evolution of the progress of meteorology in western Europe is worth noticing. For its development, Romanian scientific meteorological terminology resorted to borrowings and calques from French and English (cf. Gh. Bârlea, Roxana-Magdalena Bârlea, Lexicul românesc de origine franceză, Editura Bibliotheca, Tîrgoviște, 2000), and only occasionally to internal creations, thus succeeding in affirming itself as a perfectly functional system.

In her study Din istoria discursului meteorologic: „Buletinul atmosferic” în proza românească din anii 1884 [From the History of the Meteorological Discourse: "The Atmospheric Bulletin" in Romanian Prose from the Year 1884] (p. 241-258), Rodica Zafiu attempts to identify the main "features of The Romanian weather bulletins, in it is incipient phase of its development, on the base of a corpus of texts (60 weather forecasts)" (p. 224), excerpted from the Romania press at the end of the $19^{\text {th }}$ century and the beginning of the $20^{\text {th }}$. Throughout the period, we may remark, among other things, the evolution of the "Atmospheric Bulletin" from its early, more rigorously scientific form, to one that addressed ever larger audiences. Thus, "from the formula of technical information, it gradually developed into a type of text more adequate to journalism, and oriented to the large non-specialist public" (p. 244). "The influence of French on the formation of the terminology and Romanian meteorological discourse in the 19th century is considerable. The parallel versions (in Romanian and French) which the Meteorological Institute used to send to the newspapers of those 
times give us an accurate image of this..." (loc. cit.). The definition of weather bulletin is worth quoting: "The meteorological bulletin is a kind of formulistic text, with a high degree of stereotypy, informative, circulated by the mass-media. Its source is specialized and institutionalized source (the basic information and its original form are the product of specialized institutions), yet the massage is aimed at a wider audience." (p. 242).

The language of the weather forecasts its treated from a lexical, semantic, stylistic and syntactictextual perspective. The dominant semantic fields, i.e. of time, space, of meteorological phenomena and their quantitative appreciation of their intensity are denotative-referential.

The linguist retains a defining feature of the meteorological language: "The distinction between popular and educated elements, between the traditional vocabulary and modern borrowings is not entirely free of ambiguity: old and popular terms could be both the result of an attempt to construct a terminology by specializing the traditional vocabulary, and by means of selections dictated by the need of accessibility characteristic of the journalist text" (p. 245), and, in conclusion, he adds: "The weather bulletins from the end of the $19^{\text {th }}$ century and the beginning of the $20^{\text {th }}$ century gradually distance themselves from the style of elliptic and strictly specialized notations, however they did not reach the level of innovations and the stylistic hybridity that characterize the massmedia discourse in the $21^{\text {st }}$ century." ( $p$ 257).

With erudition, and a deep sensitivity to dialectal phenomena, Nistor Bardu, dialectologist and Romanist from “Ovidius” University of Constanța, makes a comprehensive and interesting presentation of meteorologisms in the Aromanian dialect, in a study entitled Denotație și conotație in termenii meteo din aromână [Denotation and Connotation in the Meteorological Terms in Aromanian] (p. 259272). Aromanian meteorological terms are constantly compared to their equivalents in MeglenoRomanian and Istro-Romanian, so that we can say that his study offers a panorama of meteorological language (popular, by the very nature of things!) from all the Romanian south-Danubian dialects and highlights the noteworthy unity of Romanian, in this domain.

Maria Iliescu, from Institut für Romanistik, Universität Innsbruck, focalizes on the specifically Ro- manian characteristics of the lexical field of temperature, in her study, Une caractéristique du roumain dans le champ lexical de la température (p. 273-280). Her main objective is to identify the linguistic means Romanian has in order to express the notion 'pas tout à fait chaud' (expressed in Latin by tepidus), starting from the scalar axis of temperature between the Latin antonyms calidus $\neq$ frigidus, where 0 is the prototype of this quality. Practically, depending on the language, the gradual axis which unites the two characteristics regarding temperature is open linguistically, "dans le sens qu'il accepte un nombre illimite de termes" (p. 273). That is why, the terms with the sense 'qui n'est pas tout à fait chaud' are searched for, more precisely, those between 'chaud' and 'zéro'. Considering insufficient the data offered by Romanian lexicographic works, the author uses French as an intermediary (where tepidus has been inherited under the form tiède) and the Trésor de la langue française, in its electronic version (TLFi) as source. The Romanian equivalents were identified as follows: of the 380 de occurrences of tiede excerpted from TLFi, the author translated 100 into Romanian, and then checked her translations with three different speakers of Romanian. The Romanian equivalents-călduţ, cald, răcoros, agreabil, plăcut_-are then commented upon semantically and contextually. The imprecision of tepidus (cf. Lat. tectum tepidus) could, have caused the disappearance of the words from Oriental Romania, while the short semantic distance between Romanian călduț and cald, on the axis of temperature, has favored the replacement of one by the other, while in French, the distance been greater, tiede and chaud have not substituted each other.

Mariana Neț, from "I. Iordan - Al. Rosetti" Institute of Linguistics of the Romanian Academy in Bucharest, completes the picture of Romanian meteorology, with her study on Variante sincronice și diacronice in vocabularul gastronomic românesc. Grupuri verbale formate cu substantivele "ploaie" și „zäpadă" [Synchronic and diachronic variants in the Romanian gastronomic vocabulary. Verbal groups formed with the noun 'rain' and 'snow'] (p. 281292). Of great interest is the interdisciplinary and somewhat exotic characteristics of the topic proposed, from which very inserting observations derive. Thus, the fact that Romanian gastronomic vocabulary as a sub-code of literary language developed 
rather late (approximately between 1841 and 1935, the years of the apparition of some cooking books published M. Kogălniceanu and C. Negruzzi, and by C. Bacalbaşa respectively) made room for creativity and stylistic variety. The meteorological terms mentioned above sometimes appear in regional synonyms, even in the structure of some metaphorical formulations (such as: a turna in ploaie [to pour], a face omăt [to snow]), which strictly belong to this language. In addition, the author identifies a number of expressions proper to this domain only, which do not figure in Dicționarul limbii române [The Dictionary of Romanian], such as: a turna în/sub formă de/în formă de ploaie [to pour], a bate zăpadă/ca zăpada [to snow], etc., and whose inclusion she recommends.

Pages 293 to 311 reunite the summaries (in French and in English) of the studies that precede the DFA, which only increases the addressability of the whole volume, not only of the dictionary.

One can assert that the former part of the work gives us the chance to see linguistics in action, as method and as instrument, in the service of an extremely complex scientific domain, such as meteorology. At the same time, here one can notice how, by circumscribing the meteorological domain, linguistics turns to itself. Moreover, one may notice how the scientific terminology of a particular domain of knowledge such as meteorology "overflows" from the more advanced communities of users to the less advanced ones until the gap between them is filled. As for the popular meteorological terminology, brought for the first time to the attention of specialists and non-specialists it remains to be seen to what extent this responds to the needs of the community, to which it continuously readjusts itself.

The latter part, from pages 326 to 678 , devoted to the dictionary, opens with necessary explanatory notes regarding the DFA Norms (p. 313-323), signed by Cristina Florescu, Laura Manea and Elena Tamba. Given the number and the importance of word combinations and syntagms, in St in particular, the clarification of the meaning in which the term is used proves to be extremely useful (p. 314). Also worth mentioning is the authors' idea of adapting the definitions of meteorological terms to Pt or St respectively ["the explanatory elements are rendered in the popular register for the Pt meanings and in the scientific one for $S t$ (while reserving the rébours of transparency of specialized expression - emphasis added)" (p. 316)], and of "avoiding too general indications of the type «regional», «throughout Muntenia »" in $\operatorname{Pt}$ (p. 318).

In the end, we would like to underline, once more, the elements of originality in Dicționarul fenomenelor atmosferice [The Dictionary of Atmospheric Phenomena], as well as the authors' effort "to recuperate (only partially, whenever the need of research imposed and the linguistic documentation allowed this) both the etymology of words and their regional meanings, as well as of the syntagms used in the scientific language of meteorology" (p. 21). To this end, they used earlier significant works in the field, and specialized sites.

"The fact that each dictionary entry is signed by its author, thus individualizing the contribution of each member of the team" (p. 164) is another absolute novelty of the DFA. Whenever, completions, modifications, and other interventions in the text occurs, the name of the person who did this appears at the end of the entry. The DFA introduces "new lexemes, variants and meanings, at the level of the popular lexicon, (...) in Romanian lexicography"; at the same time, "the etymological clarifications" and the authors" attempts "to recuperate the etymology of the syntagms currently used in scientific meteorological language" (p. 171), are, in fact, elaborate discussions of uncertain etymologies, and, as a consequence, on many occasions, they come up with viable solutions that argue convincingly either in favor or against the existing ones.

In the end, we would like to underscore the complexity and the outstanding value of the authors' work, who thus provide researchers and other interested parties with a comprehensive meteorological terminology that brings together words and constructions used by specialists, and those belonging to the regional, common and popular registers of Romanian. 